\title{
Optimization of Penicillium Lagena Medium Cultivication on Antifungal Pathogen of Phellinus Lamaoensis Using Surface Methode
}

\author{
Siti Nabilah $^{1}$, Rofiq Sunaryanto ${ }^{2 *}$, Khaswar Syamsu ${ }^{3}$ \\ ${ }^{I}$ Departement of Biotechnology, Bogor Agriculture University, Bogor, Indonesia 16680 \\ ${ }^{2}$ Center of Biotechnology, Agency of The Assessment and Application of Technology (BPPT), \\ Gd. 630 Kawasan Puspiptek Serpong, Tangerang Selatan, Banten, Indonesia 15314 \\ ${ }^{3}$ Departement of Agroindustrial Technology, Bogor Agriculture University, Bogor, Indonesia 16680
}

\begin{abstract}
Phellinus lamaoensis (Murr.) Hein is fungal pathogen that can cause brown root rot disease in cocoa, tea, rubber, and coffee plants. Endophytic fungi, Penicillium lagena, isolated from bandotan (Ageratum conyzoides Linn.), medicinal plant, is able to inhibit the growth of pathogenic, P. lamaoensis. The effect of carbon source, nitrogen source, and mineral solution was studied. Lactose, yeast extract, and mineral solution were media components which showed significant effect toward production of P. lagena active compound. Composition optimization of these three medium components was done by response surface methodology (RSM). The Optimal response region of the significant factor was predicted by using a second order polynomial model with statistical design, central composite design (CCD). Higest production of P. lagena active compound by quadratic model was predicted to be $69.233 \%$ with medium composition 44.77 $\mathrm{g} \mathrm{L}^{-1}$ lactose, $13.02 \mathrm{~g} \mathrm{~L}^{-1}$ yeast extract, and $15.95 \mathrm{~mL} \mathrm{~L}^{-1}$ mineral solution. Verification value in laboratory is $58.365 \%$, lower $15.7 \%$ than its prediction. Optimization increase P. lagena active compound 9 fold compared to unoptimize media.
\end{abstract}

Keywords: active compound; optimization; Penicillium lagena; RSM

\begin{abstract}
[Judul: Optimasi Media Kultivasi Penicillium Lagena pada patogen anti jamur Phellinus lamaoensis Menggunakan Metodologi Surface] Phellinus lamaoensis (Murr.) Hein merupakan jamur patogen yang dapat menyebabkan penyakit akar cokelat pada tanaman kakao, teh, karet, dan kopi. Fungi endofit Penicillium lagena yang diisolasi dari tanaman obat bandotan (Ageratum conyzoides Linn.) diketahui mampu menghambat pertumbuhan patogen P. lamaoensis. Penelitian ini bertujuan untuk mencari sumber karbon, nitrogen, dan mineral terbaik yang menghasilkan senyawa aktif P. lagena sebagai antifungi patogen P. lamaoensis dengan kadar tertinggi. Laktosa, yeast extract, dan larutan mineral adalah komponen media yang menunjukkan pengaruh yang nyata terhadap produksi senyawa aktif $P$. lagena. Optimasi ketiga komponen media tersebut dilakukan dengan response surface methodology (RSM). Optimasi terhadap faktor yang signifikan diprediksi dengan model ordo dua melalui rancangan statistika central composite design (CCD). Produksi senyawa aktif P. lagena tertinggi yang diprediksi oleh model kuadratik mencapai $69.233 \%$ dengan komposisi media $44.77 \mathrm{~g} \mathrm{~L}^{-1}$ laktosa, $13.02 \mathrm{~g} \mathrm{~L}^{-1}$ yeast extract, dan $15.95 \mathrm{~mL} \mathrm{~L}^{-1}$ larutan mineral. Hasil verifiksasi di laboratorium sebesar $58.365 \%$, lebih rendah 15,7\% dibandingkan prediksinya. Optimasi meningkatkan senyawa aktif P. lagena 9 kali lipat dibandingkan sebelum optimasi
\end{abstract}

Kata kunci: optimasi; Penicillium lagena; RSM; senyawa aktif

\section{Introduction}

Phellinus lamaoensis (Murr.) Hein, which the synonyms are Fomes noxius Corner or Fomes lamaoensis Murr., causes brown root rot disease in cocoa, tea, rubber, and coffee plants (Semangun, 2000). The attack of brown

\footnotetext{
${ }^{*}$ Penulis Korespondensi.

E-mail: rofiqsn@yahoo.com
}

root rot disease is able to decrease 50 percent of the cacao plantation population (Pusat Penelitian Kopi dan Kakao Indonesia 2010). P lamaoensis attacks cacao in several countries, such as Indonesia, Ghana, Nigeria, Sri Lanka, Malaysia, Papua New Guinea, and Samoa. The spread of root disease is through direct contact between healthy roots with infected root. Trees that are infected will die after six months of infection (Wood, Lass, 1989). 
Prevention brown root rot disease was late because the spread of disease was slow and the infection of pathogens was unknown since beginning. Plants that have died which were caused by the disease were dismantled and burnt, then the remaining holes were given 100-600 grams of sulfur and this land can be used again one year later (Nazaruddin, Paimin, 1992; Eden, 1965). Gas of $\mathrm{SO}_{2}$ or $\mathrm{SO}_{3}$ in sulfur can react with water vapor in the air to form $\mathrm{H}_{2} \mathrm{SO}_{3}$ or $\mathrm{H}_{2} \mathrm{SO}_{4}$ which can cause acid rain (Triharso, 1994). Acid rain causes the damage of forests and eroded the fertile soil layer. Disease control using chemicals are less effective and could negatively affect the environment and human health (Mejía et al., 2008).

Controlling the disease can be done with biological control, endophytic fungi. Endophyte are microorganisms (normally fungi and bacteria) that exist in almost every tissue of a plant but do not cause harm or infect plants. Some endophyte produce active compounds in secondary metabolites as anticancer, antioxidant, antiviral (Selim et al., 2012), antibacterial and antifungal ( Tran et al., 2010). Endophyte fungi, $P$. lagena, which was isolated from herbal, bandotan (Ageratum conyzoides Linn.), is able to inhibit the growth of pathogenic, P. lamaoensis (Kaswati, 2013). Bandotan is an annual herb plant in Asteraceae family (Dalimartha, 2006).

Herbal plants are shortages caused by the slow regeneration and the increasing human population resulting in environmental degradation and decline in biodiversity (Wilson, 1988). Scarcity of herbal plants becomes obstacles to isolation $P$. lagena. Therefore, It needs to optimize growth medium $P$. lagena to produce the active compound which is able to kill the pathogen $P$. lamaoensis. The conventional method for the optimization of cultivation media is done by changing one parameter while other parameters are fixed (Liu,Tzeng, 1998). This method may lead to misinterpretation of the results, especially when the effects of the interaction between different factors are ignored. Response Surface Methodology (RSM) is a combination of mathematical and statistical techniques to establish an empirical model. Optimization cultivation using statistical methods can minimize the number of experiments carried out so that it can save costs, time, and effort. RSM in optimization of cultivation can combine all the factors involved in cultivation (Lepsch, McMillin, 1998).

\section{Materials and Methods}

\subsection{Microorganism}

Penicillium lagena and Phellinus lamaoensis are cultural stock in BPPT-Biotek Serpong, Tangerang Selatan. It was grown on agar medium and was incubated at $28^{\circ} \mathrm{C}$ for 5 days.

\subsection{Inoculum preparation}

$6 \mathrm{~mL} \mathrm{NaCl}$ physiologic is augmented to Penicillium lagena on agar medium and $1 \mathrm{~mL}$ was transferred to $50 \mathrm{~mL}$ sterile vegetative medium in $500 \mathrm{~mL}$ Erlenmeyer with glass bead. The composition of vegetative medium consisted of $10 \mathrm{~g} \mathrm{~L}^{-1}$ rice flour, $10 \mathrm{~g} \mathrm{~L}^{-}$ ${ }^{1}$ glucose, $20 \mathrm{~g} \mathrm{~L}^{-1}$ soybean meal, $1 \mathrm{~g} \mathrm{~L}^{-1} \mathrm{KH}_{2} \mathrm{PO}_{4}$, and 0.5 $\mathrm{g} \mathrm{L}^{-1} \mathrm{MgSO}_{4} \cdot 7 \mathrm{H}_{2} \mathrm{O}, \mathrm{pH}$ adjusted at 5.8. Vegetative culture is incubated at $25^{\circ} \mathrm{C}, 220 \mathrm{rpm}$ for 48 hours.

\subsection{Production culture for determination of the best of carbon and nitrogen source}

Cultivation medium for determination of the carbon source consisted of $10 \mathrm{~g} \mathrm{~L}^{-1}$ malt extract, $10 \mathrm{~g} \mathrm{~L}^{-1}$ yeast extract, $1 \mathrm{~g} \mathrm{~L}^{-1}$ tryptone, $1 \mathrm{~g} \mathrm{~L}^{-1} \mathrm{KH}_{2} \mathrm{PO}_{4}, 1 \mathrm{~g} \mathrm{~L}^{-1}$ $\mathrm{NH}_{4} \mathrm{NO}_{3}$, and carbon from four different sources: lactose, galactose, maltose, and glucose. Cultivation medium for determination of the nitrogen source consisted of $30 \mathrm{~g} \mathrm{~L}^{-1}$ glucose, $20 \mathrm{~mL} \mathrm{~L}^{-1}$ glycerol, $10 \mathrm{~g} \mathrm{~L}^{-1}$ dexstrin, $1 \mathrm{~g} \mathrm{~L}^{-1}$ $\mathrm{KH}_{2} \mathrm{PO}_{4}$, and nitrogen from four different sources, namely yeast extract, malt extract, tripton, and $\mathrm{NH}_{4} \mathrm{NO}_{3}$. Cultivation $P$. lagena was conducted with shake culture $25 \mathrm{~mL}$ volume $\mathrm{pH}$ adjusted at $5.9,25^{\circ} \mathrm{C}, 220 \mathrm{rpm}$ for 5 days on Erlenmeyer $250 \mathrm{~mL}$. Active compound from each medium was extracted and injected to HPLC. The wide area curved was considered as concentration of active compound of $P$. lagena.

\subsection{Production culture for determination of the best of mineral concentration}

According to Ghatora et al. (2006) mineral solution for cultivation medium of $P$. lagena consists of $0.02 \mathrm{~g} \mathrm{~L}^{-1}\left(\mathrm{NH}_{4}\right)_{2} \mathrm{SO}_{4}, 0.05 \mathrm{~g} \mathrm{~L}^{-1} \mathrm{KCl}, 0.01 \mathrm{~g} \mathrm{~L}^{-1} \mathrm{CaCl}_{2}$, $0.05 \mathrm{~g} \mathrm{~L}^{-1} \mathrm{MgSO}_{4}, 0.001 \mathrm{~g} \mathrm{~L}^{-1} \mathrm{ZnSO}_{4}$, dan $0.0005 \mathrm{~g} \mathrm{~L}^{-1}$ $\mathrm{CuSO}_{4}$. Mineral solution was augmented to cultivation medium of $P$. lagena $0,20,40,60$, and $80 \mathrm{~mL} \mathrm{~L}^{-1}$, respectively. Cultivation $P$. lagena was conducted with shake culture $25 \mathrm{~mL}$ volume $\mathrm{pH}$ adjusted at $5.9,25^{\circ} \mathrm{C}$, $220 \mathrm{rpm}$ for 5 days on Erlenmeyer $250 \mathrm{~mL}$. Medium with highest concentration of active compound was used for optimization medium.

\subsection{Extraction of active compound}

According to Kaswati (2013), bioactive compound of $P$. lagena is extracellular. Cultivation medium was centrifuged at $8000 \mathrm{rpm}$ for 15 second. Supernatant was extracted with ethyl acetate ratio $1: 1(\mathrm{v} / \mathrm{v})$ and shaken for 30 second. Ethyl acetate phase was dried with centrifugal concentrator. Extracellular extract was weighed and was adjusted to $5000 \mathrm{ppm}$ concentration and was injected to HPLC.

\subsection{Experimental design and optimization by RSM}

Designing of optimization medium uses central composite design (CCD). The CCD consisted of three designs, namely design of factorial $2^{3}$, starting point, and center point. Factorial and starting point were done in two replicates whereas center point was done six replications, resulting in 34 experiments. Factors and levels that were 


\section{Teknik, 38 (2), 2017, 60}

used in central composite design is shown on Table 1. Cultivation $P$. lagena was conducted with shake culture $25 \mathrm{~mL}$ volume $\mathrm{pH}$ adjusted at $5.9,25^{\circ} \mathrm{C}, 220 \mathrm{rpm}$ for 5 days on erlenmeyer $250 \mathrm{~mL}$.

Table 1. Factors and levels that were used in central composite design

\begin{tabular}{lccccc}
\hline \multirow{2}{*}{ Factors } & \multicolumn{5}{c}{ Levels } \\
\cline { 2 - 6 } & $\mathbf{- 1 . 6 8}$ & $\mathbf{- 1}$ & $\mathbf{0}$ & $\mathbf{1}$ & $\mathbf{1 . 6 8}$ \\
\hline Lactose $\left(\mathrm{g} \mathrm{L}^{-1}\right)$ & 25.99 & 33.61 & 44.81 & 56.01 & 63.63 \\
Yeast extract $\left(\mathrm{g} \mathrm{L}^{-1}\right)$ & 3.76 & 7.16 & 12.16 & 17.16 & 20.56 \\
Mineral solution $\left(\mathrm{mL} \mathrm{L}^{-1}\right)$ & 0 & 4.05 & 10 & 15.95 & 20 \\
\hline
\end{tabular}

The behavior of the system was explained by the following second order polynomial equation:

$\mathrm{Y}=\mathrm{b}_{0}+\mathrm{b}_{1} \mathrm{X}_{1 \mathrm{i}}+\mathrm{b}_{2} \mathrm{X}_{2 \mathrm{i}}+\mathrm{b}_{3} \mathrm{X}_{3 \mathrm{i}}+\mathrm{b}_{11} \mathrm{X}_{1}{ }^{2}+\mathrm{b}_{22} \mathrm{X}_{2}{ }^{2}+\mathrm{b}_{33} \mathrm{X}_{3}{ }^{2}+$

$$
b_{12} X_{1} X_{2}+b_{13} X_{1} X_{3}+b_{23} X_{2} X_{3}
$$

$\mathrm{Y}=$ wide area (response)

$\mathrm{X}_{1}=$ source of carbon concentration $\left(\mathrm{g} \mathrm{L}^{-1}\right)$

$\mathrm{X}_{2}=$ source of nitrogen concentration $\left(\mathrm{g} \mathrm{L}^{-1}\right)$

$\mathrm{X}_{3}=$ volume of mineral solution $\left(\mathrm{mL} \mathrm{L}^{-1}\right)$

The model was verified with five replication in the laboratory for the testing the suitability of the model.

\section{Results and Discussion}

Microorganisms need water, carbon, nitrogen, minerals, and oxygen if the aerob is in the process of cultivation. Materials with the appropriate concentration in the cultivation medium can produce the desired product optimally. Relative percentage wide area of antifungal compound of lactose is the highest than galactose, maltose and glucose. The result of further test with Duncan test on a probability level 0.05 shows that lactose, maltose, and glucose were significantly different but lactose and galactose were not significantly different (Figure 1). Lactose was chosen as the best carbon source.

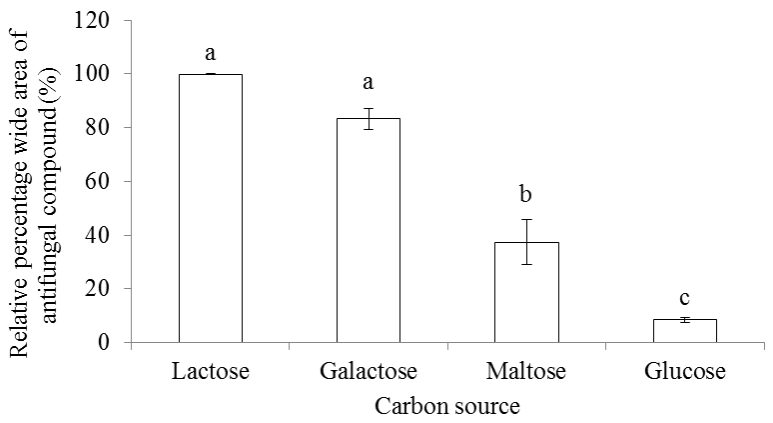

Figure 1. Relative percentage wide area of antifungal compound of some carbon sources. The vertical line at the top of each block of data indicates standard error and letters above blocks of data shows the comparison of the mean of carbon source based on Duncan multiple comparison test with probability level of 0.05
In the HPLC, a wide area is proportional to the concentration of the solute in the flow cell (tested compounds) (Lough, Wainer, 1996). Carbon is required by microorganisms for biosynthesis and as a source of energy (Stanbury et al., 2003).

Relative percentage wide area of antifungal compound of yeast extract is the highest than malt extract, tripton and $\mathrm{NH}_{4} \mathrm{NO}_{3}$. The result of the further test with Duncan test on a probability level 0.05 shows that yeast extract was significantly different from tripton and $\mathrm{NH}_{4} \mathrm{NO}_{3}$ but it was not different from malt extract. Malt extract with tripton was not also different (Figure 2). Yeast extract was chosen as the best nitrogen source.

Nitrogen source was as the supply of amino acid, protein, or urea (Stanbury et al., 2003). Yeast extracts are excellent substrates for many microorganism on fermentation process because it contains amino acid and peptides, water-soluble vitamins, and carbohydrates (Crueger, Crueger, 1984).

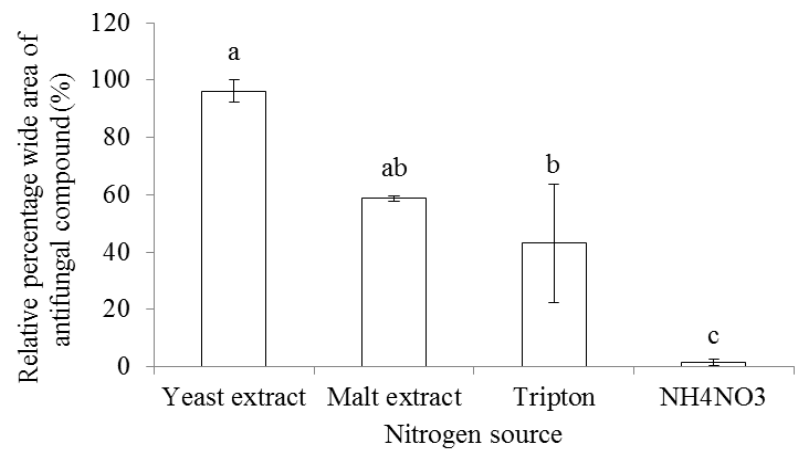

Figure 2. Relative percentage wide area of antifungal compound of some nitrogen sources. The vertical line at the top of each block of data indicates the standard error and letters above blocks of data shows the comparison of the mean of nirogen source based on Duncan multiple comparison test with probability level of 0.05

Relative percentage wide area of antifungal compound in cultivation medium without mineral solution is lower than cultivation medium with mineral solution. The results of further test with Duncan test on a real level 0.05 shows that relative percentage wide area of antifungal compound of cultivation medium without mineral solution was different with cultivation medium with mineral solution. However the concentration of mineral solution $\left(20,40,60\right.$, and $\left.80 \mathrm{~mL} \mathrm{~L}^{-1}\right)$ was not significantly different (Figure 3). Mineral with concentration $0-20 \mathrm{~mL} \mathrm{~L}^{-1}$ was chosen for the next step. Minerals are needed by all microorganisms for growth and metabolism (Stanbury et al., 2003). 


\section{Teknik, 38 (2), 2017, 61}

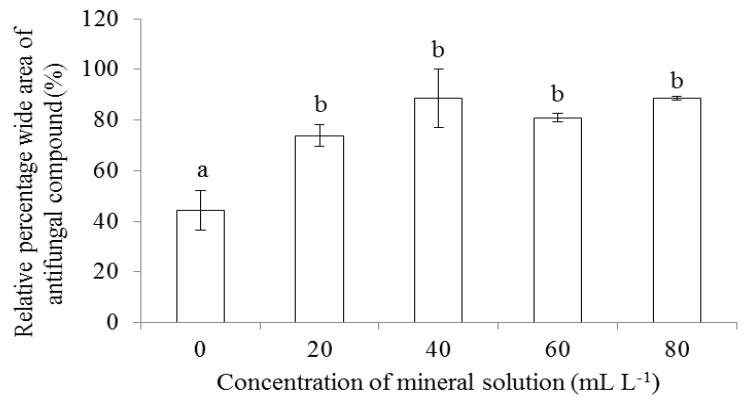

Figure 3. Relative percentage wide area of antifungal compound of several concentration of mineral solution. The vertical line at the top of each block of data indicates standard error and letters above blocks of data shows the comparison of the mean of concentration mineral solution based on Duncan multiple comparison test with probability level of 0.05

The design of optimization medium is using a central composite design (CCD) with three variables, namely lactose, yeast extract, and minerals. The experimental design is encoded for each factor, -1 lower limit, 0 middle limit, 1 upper limit, and 1.68 or -1.68 starting point with value for each code and factor based on Table 1. Data analysis of responses to the optimization of cultivation media (Table 2) were tested with Sequential Model Sum of Square (Table 3) and indicates that the quadratic vs. 2 FI model is significant $(p=0.0002)$ and suggested. Model summary statistics (Table 4) shows that the quadratic model has the largest adjusted $\mathrm{R}$-squared value among the others, i.e. 0.5025. Adjusted R-squared shows that three variables effect of diversity responses by $50.25 \%$ while the rest is influenced by the other variables which were not examined. PRESS value (prediction error sum of squares) quadratic model is the lowest. This suggests that the quadratic model is the best fit model.

Results of analysis of variance for quadratic model (Table 5) shows that the quadratic model significantly $(p=0.0011)$ affect the response. The influence of linear $\left(\mathrm{X}_{2} \mathrm{X}_{3}\right)$ and quadratic also showed significant results $(p<0.05)$. The result of Lack of fit was not significant $(p=0.1846)$ indicating that the quadratic model is the right model. The test of center point produces error pure value. Comparison of the mean square lack of fit with pure error results in the F test that if the results are not significant indicates that the model is the right model (Bradley, 2007). Quadratic equation obtained:

$\mathrm{Y}=72.6459-2.1532 \mathrm{X}_{1}+1.4704 \mathrm{X}_{2}+4.1495 \mathrm{X}_{3}+$ $2.5949 \mathrm{X}_{1} \mathrm{X}_{2}+5.2990 \mathrm{X}_{1} \mathrm{X}_{3}+6.9158 \mathrm{X}_{2} \mathrm{X}_{3}-$ $13.3402 \mathrm{X}_{1}^{2}-10.4027 \mathrm{X}_{2}^{2}-8.6880 \mathrm{X}_{3}^{2}$

$\mathrm{Y}=$ relative percentage wide area of antifungal compound (response)

$\mathrm{X}_{1}=$ source of carbon concentration $\left(\mathrm{g} \mathrm{L}^{-1}\right)$

$\mathrm{X}_{2}=$ source of nitrogen concentration $\left(\mathrm{g} \mathrm{L}^{-1}\right)$

$\mathrm{X}_{3}=$ volume of mineral solution $\left(\mathrm{mL} \mathrm{L}^{-1}\right)$
The negative sign (-) in the quadratic coefficient $\left(\mathrm{X}_{1}^{2}, \mathrm{X}_{2}^{2}\right.$, and $\left.\mathrm{X}_{3}^{2}\right)$ indicates that the response graph obtained is a maximum or graph a parabola opens downward (Montgomery, 2001).

Table 2. Data analysis of responses to the optimization of cultivation media with central composite design

\begin{tabular}{|c|c|c|c|c|}
\hline Std & $\begin{array}{c}\text { Lactose } \\
\left(\mathrm{g} \mathrm{L}^{-1}\right)\end{array}$ & $\begin{array}{c}\text { Yeast } \\
\text { extract } \\
\left(\mathrm{g} \mathrm{L}^{-1}\right)\end{array}$ & $\begin{array}{l}\text { Mineral } \\
\left(m L L^{-1}\right)\end{array}$ & $\begin{array}{c}\text { Relative percentage } \\
\text { wide area of } \\
\text { antifungal compound } \\
(\%)\end{array}$ \\
\hline 1 & -1 & -1 & -1 & 54.990 \\
\hline 2 & -1 & -1 & -1 & 60.164 \\
\hline 3 & 1 & -1 & -1 & 29.272 \\
\hline 4 & 1 & -1 & -1 & 44.425 \\
\hline 5 & -1 & 1 & -1 & 65.682 \\
\hline 6 & -1 & 1 & -1 & 28.023 \\
\hline 7 & 1 & 1 & -1 & 17.480 \\
\hline 8 & 1 & 1 & -1 & 29.121 \\
\hline 9 & -1 & -1 & 1 & 44.413 \\
\hline 10 & -1 & -1 & 1 & 45.183 \\
\hline 11 & 1 & -1 & 1 & 33.324 \\
\hline 12 & 1 & -1 & 1 & 30.799 \\
\hline 13 & -1 & 1 & 1 & 40.994 \\
\hline 14 & -1 & 1 & 1 & 56.071 \\
\hline 15 & 1 & 1 & 1 & 59.987 \\
\hline 16 & 1 & 1 & 1 & 58.774 \\
\hline 17 & -1.68 & 0 & 0 & 34.499 \\
\hline 18 & -1.68 & 0 & 0 & 15.591 \\
\hline 19 & 1.68 & 0 & 0 & 22.471 \\
\hline 20 & 1.68 & 0 & 0 & 47.555 \\
\hline 21 & 0 & -1.68 & 0 & 30.447 \\
\hline 22 & 0 & -1.68 & 0 & 38.320 \\
\hline 23 & 0 & 1.68 & 0 & 40.237 \\
\hline 24 & 0 & 1.68 & 0 & 44.347 \\
\hline 25 & 0 & 0 & -1.68 & 29.144 \\
\hline 26 & 0 & 0 & -1.68 & 35.543 \\
\hline 27 & 0 & 0 & 1.68 & 53.441 \\
\hline 28 & 0 & 0 & 1.68 & 54.623 \\
\hline 29 & 0 & 0 & 0 & 59.093 \\
\hline 30 & 0 & 0 & 0 & 77.269 \\
\hline 31 & 0 & 0 & 0 & 55.090 \\
\hline 32 & 0 & 0 & 0 & 70.436 \\
\hline 33 & 0 & 0 & 0 & 77.340 \\
\hline 34 & 0 & 0 & 0 & 100 \\
\hline
\end{tabular}




\section{Teknik, 38 (2), 2017, 62}

Table 3. Sequential Model Sum of Square for response for relative percentage wide area of active compound $P$. lagena

\begin{tabular}{lcccccc}
\hline \multicolumn{1}{c}{ Source } & $\begin{array}{c}\text { Sum of } \\
\text { Squares }\end{array}$ & Df & $\begin{array}{c}\text { Mean } \\
\text { Square }\end{array}$ & $\begin{array}{c}\text { F } \\
\text { Value }\end{array}$ & $\begin{array}{c}\text { p- } \\
\text { value } \\
\text { Prob } \\
>\text { F }\end{array}$ & Description \\
\hline $\begin{array}{l}\text { Mean vs. } \\
\text { Total }\end{array}$ & 73809.8353 & 1 & 73809.8353 & & & \\
$\begin{array}{l}\text { Linear vs. } \\
\text { Mean }\end{array}$ & 655.9748 & 3 & 218.6583 & 0.6082 & 0.6149 & \\
$\begin{array}{l}\text { FI vs. } \\
\text { Linear }\end{array}$ & 1322.2684 & 3 & 440.7561 & 1.2576 & 0.3086 & \\
$\begin{array}{l}\text { Quadratic } \\
\text { vs. 2FI }\end{array}$ & 5323.1898 & 3 & 1774.3966 & 10.2874 & 0.0002 & Suggested \\
$\begin{array}{l}\text { Cubic vs. } \\
\text { Quadratic }\end{array}$ & 796.9907 & 4 & 199.2477 & 1.1922 & 0.3447 & Aliased \\
$\begin{array}{l}\text { Residual } \\
\text { Total }\end{array}$ & 3342.6059 & 20 & 167.1303 & & & \\
\hline
\end{tabular}

Table 4. Model summary statistics for response for relative percentage wide area of active compound $P$. lagena

\begin{tabular}{lccccrl}
\hline Source & $\begin{array}{c}\text { Std. } \\
\text { Dev. }\end{array}$ & $\begin{array}{c}\text { R- } \\
\text { Squared }\end{array}$ & $\begin{array}{c}\text { Adjusted } \\
\text { R-Squared }\end{array}$ & $\begin{array}{c}\text { Predicted } \\
\text { R- }\end{array}$ & PRESS & Description \\
\hline Linear & $\begin{array}{c}18.960 \\
5\end{array}$ & 0.0573 & -0.0369 & -0.1289 & 12915.911 & \\
& 18.720 & & & & 1 & \\
2FI & 9 & 0.1729 & -0.0109 & -0.0921 & 12494.728 & \\
Quadrati & 13.133 & 0.6382 & 0.5025 & 0.2955 & 8059.8775 & Suggested \\
c & 3 & & & & & \\
Cubic & 12.927 & 0.7078 & 0.5179 & 0.2100 & 9037.9833 & Aliased \\
\hline
\end{tabular}

Table 5. Analysis of variance for response surface of quadratic model

\begin{tabular}{|c|c|c|c|c|c|c|}
\hline Source & $\begin{array}{l}\text { Sum of } \\
\text { Squares }\end{array}$ & df & $\begin{array}{c}\text { Mean } \\
\text { Square }\end{array}$ & $\begin{array}{c}F \\
\text { Value }\end{array}$ & $\begin{array}{c}\text { p- } \\
\text { value } \\
\text { Prob > } \\
\text { F } \\
\end{array}$ & Description \\
\hline Model & 7301.4330 & 9 & 811.2703 & 4.7035 & 0.0011 & \multirow[t]{6}{*}{ Significant } \\
\hline $\begin{array}{l}\mathrm{X}_{1^{-}} \\
\text {Laktosa }\end{array}$ & 126.6323 & 1 & 126.6323 & 0.7342 & 0.4000 & \\
\hline $\begin{array}{l}\mathrm{X}_{2} \text {-Yeast } \\
\text { Extract }\end{array}$ & 59.0532 & 1 & 59.0532 & 0.3424 & 0.5639 & \\
\hline $\begin{array}{l}\mathrm{X}_{3^{-}} \\
\text {Mineral }\end{array}$ & 470.2893 & 1 & 470.2893 & 2.7266 & 0.1117 & \\
\hline $\mathrm{X}_{1} \mathrm{X}_{2}$ & 107.7385 & 1 & 107.7385 & 0.6246 & 0.4371 & \\
\hline $\mathrm{X}_{1} \mathrm{X}_{3}$ & 449.2673 & 1 & 449.2673 & 2.6047 & 0.1196 & \\
\hline $\mathrm{X}_{2} \mathrm{X}_{3}$ & 765.2625 & 1 & 765.2625 & 4.4367 & 0.0458 & Significant \\
\hline $\mathrm{X}_{1}^{2}$ & 4012.4878 & 1 & 4012.4878 & 23.2631 & $\begin{array}{c}< \\
0.0001\end{array}$ & Significant \\
\hline $\mathrm{X}_{2}{ }^{2}$ & 2439.9457 & 1 & 2439.9457 & 14.1460 & 0.0010 & Significant \\
\hline $\mathrm{X}_{3}^{2}$ & 1701.8485 & 1 & 1701.8485 & 9.8668 & 0.0044 & Significant \\
\hline Residual & 4139.5966 & 24 & 172.4832 & \multirow{4}{*}{1.6934} & \multirow{4}{*}{0.1846} & \multirow{3}{*}{$\begin{array}{c}\text { Not } \\
\text { Significant }\end{array}$} \\
\hline $\begin{array}{l}\text { Lack of } \\
\text { Fit }\end{array}$ & 1276.0813 & 5 & 255.2163 & & & \\
\hline $\begin{array}{l}\text { Pure } \\
\text { Error }\end{array}$ & 2863.5153 & 19 & 150.7113 & & & \\
\hline $\begin{array}{l}\text { Cor } \\
\text { Total }\end{array}$ & 11441.0295 & 33 & & & & \\
\hline
\end{tabular}

Response surface plot obtained as function of lactose versus yeast extract concentration (Figure 4) shows that the increase of lactose and yeast extract concentration effect on the production of active compounds $P$. lagena. Lactose concentration above 44.81 $\mathrm{g} \mathrm{L}^{-1}$ level $(0)$ and yeast extract concentration above 12.16 $\mathrm{g} \mathrm{L}^{-1}$ level (0) cause the decrease of production of active compounds $P$. lagena. Interaction between lactose with yeast extract no effect on the production of active compounds $P$. lagena $(\mathrm{p}=0.4371)$. High substrate concentrations can inhibit cell growth of microorganisms (Edwards, 1970). Inhibited cell growth causes the decrease of secondary metabolites produced.

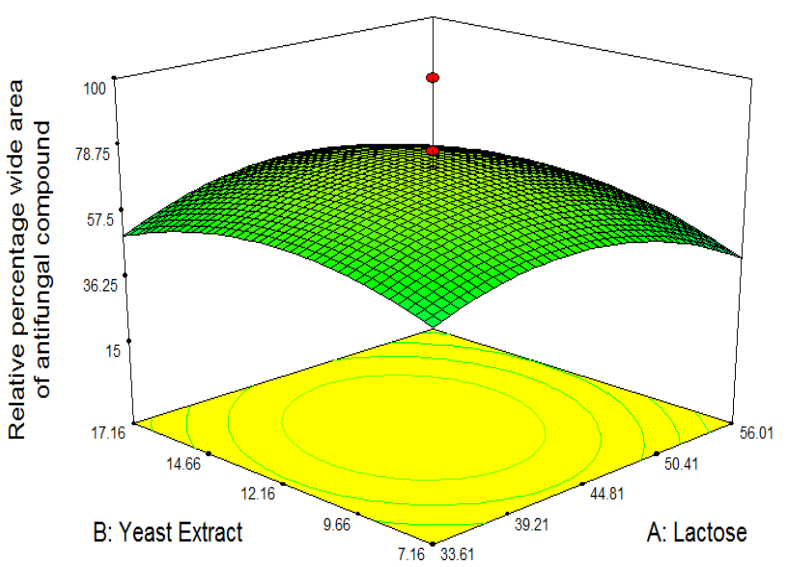

Figure 4. Response surface plot between lactose and yeast extract on the production active compound $P$. lagena

Response surface plot obtained as function of lactose versus mineral concentration (Figure 5) shows that the increasing of lactose and mineral concentration affect on the production of active compounds $P$. lagena. Lactose concentration above $44.81 \mathrm{~g} \mathrm{~L}^{-1}$ level (0) causes the decrease of the active compounds production and mineral concentration above $10 \mathrm{~mL} \mathrm{~L}^{-1}$ level (0) causes the decrease of active compounds $P$. lagena production. Ghatora et al (2006) used mineral solution for xylanase cultivation of thermophilic and thermotolerant fungi with concentration $1 \%$ or $10 \mathrm{~mL}^{-1}$. P. lagena is thermotolerant fungi. Interaction between lactose with mineral no effect on the production of active compounds P. lagena $(\mathrm{p}=0.1196)$.

Response surface plot obtained as function of yeast extract versus mineral concentration (Figure 6) shows that the increase of yeast extract and mineral concentration affects the production of active compounds $P$. lagena. Yeast extract concentration above $12.16 \mathrm{~g} \mathrm{~L}^{-1}$ level (0) causes the decrease of production of active compounds and mineral concentration above $10 \mathrm{~mL} \mathrm{~L}^{-1}$ level (0) causes the decrease of production of active compounds $P$. lagena. Interaction between yeast extract with mineral effect on the production of active compounds P. lagena (p $=0.0458$ ). 
Teknik, 38 (2), 2017, 63

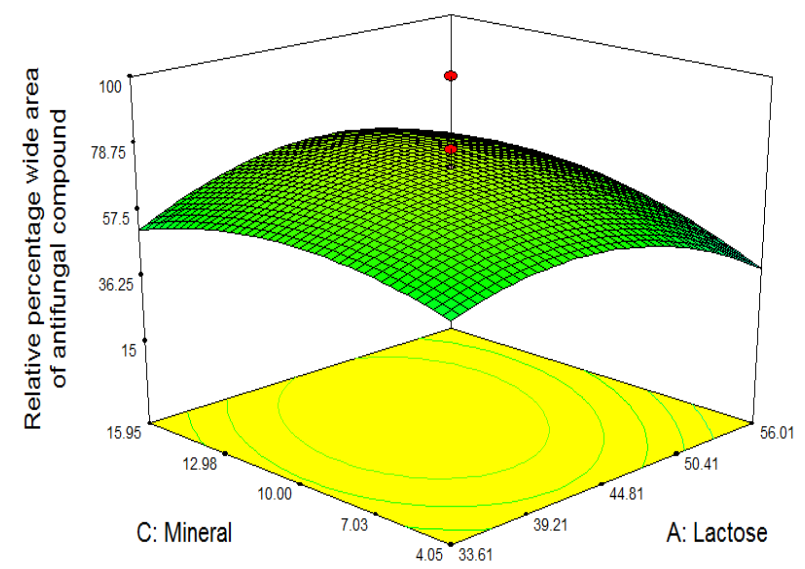

Figure 5. Response surface plot between lactose and mineral on the production of active compound P. lagena

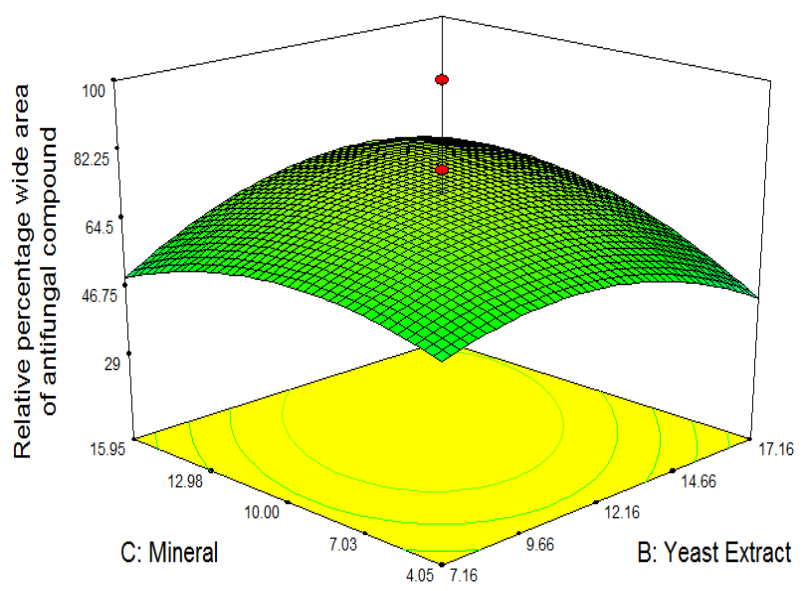

Figure 6. Response surface plot between yeast extract and mineral on the production of active compound P. lagena

The maximum percentage relative wide area response indicating the concentration of active compound $P$. lagena was to be predicted at $69.233 \%$ with media composition $44.77 \mathrm{~g} \mathrm{~L}^{-1}$ lactose, $13.02 \mathrm{~g} \mathrm{~L}^{-1}$ yeast extract, and $15.95 \mathrm{~mL} \mathrm{~L}^{-1}$ mineral. The result of the verification in the laboratory produces the active compound $P$. lagena at $58.365 \%$. This value was found to be $15.7 \%$ less than the predicted value. Results of optimization increase the production of active compounds $P$. lagena about 9 times compared with that of unoptimized medium (basal medium).

\section{Conclusion}

Components of cultivation media which are able to increase the production of active compounds $P$. lagena are lactose as a carbon source, yeast extract as a nitrogen source, and mineral additions. Production of the active compound $P$. lagena was the highest on media with the composition $44.77 \mathrm{~g} \mathrm{~L}^{-1}$ lactose, $13.02 \mathrm{~g} \mathrm{~L}^{-1}$ yeast extract, and $15.95 \mathrm{~mL} \mathrm{~L}^{-1}$ minerals. Optimization of the composition media is able to increase the production of the $P$. lagena active compound 9 times more compared to basal medium.

\section{Acknowledgement}

Thanks to the center of Biotechnology, Agency of the Assessment and Application of Technology (BPPT), Gd. 630 Kawasan Puspiptek Serpong, Tangerang Selatan who have financed and facilitated this research.

\section{Daftar Pustaka}

Bradley, N. (2007). The respone surface methodology. Thesis. Indiana University of South Bend.

Crueger, W., Crueger, A. (1984). Biotechnology. USA: Science Tech, Inc.

Dalimartha, S. (2006). Atlas Tumbuhan Obat Indonesia Jilid 2. Jakarta: Trubus Agriwidya.

Eden, T. (1965). Tea. London: Longmans, Green and Co ltd.

Edwards, V.H. (1970). The Influence of High Substrat Concentration on Microbial Kinetics. Biotechnology and Bioengineering, 12, 679-712.

Ghatora, S.K., Chandha, B.S., Badhan, A.K, Saini, H.S., , Bhat, M.K. (2006). Identification and Characterization of Diverse Xylanases from Thermophilic and Thermotolerant Fungi. Bio Resources, 1(1), 18-33.

Kaswati, N.M.N. (2013). Penapisan dan Identifikasi Senyawa Antijamur Patogen Phellinus lamaoensis dari Jamur Endofit pada Tanaman Obat Asal Cirebon. Skripsi. Institut Pertanian Bogor.

Lepsch, R.A, McMillin, M,L. (1998). Response Surface Model Building and Multidisciplinary Optimization Using D-Optimal Design. American Institute of Aeronautics and Astronautics, 98, 4759.

Liu, B.L \& Tzeng, Y.M. (1998). Optimazation of Growth Medium for Production of Spores from Bacillus thuringiensi Using Reponse Surface Methodology. Bioprocess and Biosystems Engineering, 18, 413418.

Lough, W.J., Wainer, I.W. (1996). High Performance Liquid Chromatography. Glasgow: Blackie Academic and Professional.

Mejía, L.C., Rojas, E.I., Maynard, Z., Bael, S.V., Arnold, A.E., Hebbar, P., Samuel, G.J., Robbins, N., \& Herre, E.A. (2008). Endophytic Fungi as Biocontrol Agents of Theobroma cacao Pathogens. Biological Control, 46, 4-14.

Montgomery, D.C. (2001). Design and Analysis of Experiments $5^{\text {th }}$ Edition. USA: John Wiley \& Sons, Inc.

Nazaruddin, Paimin, F.B. (1992). Karet. Bogor: Penebar Swadaya. 


\section{Teknik, 38 (2), 2017, 64}

Pusat Penelitian Kopi dan Kakao Indonesia. (2010). Buku Pintar Budi Daya Kakao. Jakarta: Agro Media Pustaka.

Selim, K.A., El-Beih, A.A., Abd El-Rahman, T.M., ElDiwany, A.I. (2012). Biology of Endophytic Fungi. Current Research in Environmental and Applied Mycology, 2(1), 31-82.doi: $10.5943 / \mathrm{cream} / 2 / 1 / 3$.

Semangun, H. (2000). Penyakit-Penyakit Tanaman Perkebunan di Indonesia. Yogyakarta: Gadjah Mada University Press.

Stanbury, P.F., Whitaker, A, Hall, S.J. (2003). Principles of Fermentation Technology $2^{\text {nd }}$ Edition. Great Britain: MPG Books Ltd.
Tran, H.B.Q., McRae, J.M., Lynch, F., Palombo, E.A. (2010). Identification and Bioactive Properties of Endophytic Fungi Isolated from Phyllodes of Accacia Species. Current Research, Technology and Education Topics in Applied Microbiology and Microbial Biotechnology, 1, 377-382.

Triharso. (1994). Dasar-Dasar Perlindungan Tanaman. Yogyakarta: Gadjah Mada University Press.

Wilson, E.O. (1988). Biodiversity. Washington DC: National Academy Press.

Wood, G.A.R., Lass, R.A. (1989). Cocoa. New York: John Wiley \& Sons, Inc. 